ECONOMICS

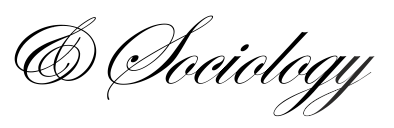

Tetyana Vasilyeva,

Sumy State University,

Sumy, Ukraine,

E-mail:

tavasilyeva@fem.sumdu.edu.ua

\author{
Serhiy Lyeonov, \\ Sumy State University, \\ Sumy, Ukraine, \\ E-mail: \\ s.lieonov@uabs.sumdu.edu.ua
}

Izabela Adamičková,

Slovak University of Agriculture in

Nitra,

Nitra, Slovakia,

E-mail:

irabela.adamickova@uniag.sk.

\author{
Kseniya Bagmet, \\ Sumy State University, \\ Sumy, Ukraine, \\ E-mail: kbagmet2017@gmail.com
}

Received: February, 2018

1st Revision: March, 2018

Accepted: May, 2018

DOI: $10.14254 / 2071-$

789X.2018/11-2/17

JEL Classification: O10, C38
Vasilyeva, T., Lyeonov, S., Adamičková, I., Bagmet, K. (2018). Institutional Guality of Social Sector: the Essence and Measurements. Economics and Sociology, 11(2), 248-262. doi:10.14254/2071-789X.2018/11-2/17

\section{INSTITUTIONAL QUALITY OF SOCIAL SECTOR: THE ESSENCE AND MEASUREMENTS}

\begin{abstract}
The article provides theoretical underpinning for the need to assess institutional quality of the social sector. Basing on the critical analysis of the existing approaches to index construction, traditionally used to study economic development and quality of life, it is proposed to form the index of social sector quality, and also the principles of its calculation are justified. The presented methodology for calculating this index is built upon the principal component analysis. The calculation includes 20 indicators, which represent three groups (education, healthcare and social security). The index creation is based on the data for 25 countries divided into four groups. According to our evaluation findings, the quality of social institutions will be primarily determined by their ability to provide an extension of average life expectancy and to maintain an adequate level of health, as well as employment according to the results of education. The quality of social security institutions' operations affects the index variability to the least extent.
\end{abstract}

Keywords: institution; institutional changes; institutional quality; social sector; principal component analysis for countries.

\title{
Introduction
}

Transformational processes that occur in many countries, including Ukraine, include, inter alia, formation of new institutions or significant changes in the existing ones. Formation of a new socioeconomic model is decisive since institutions' quality determines the transition of national economy. The importance of institutions' influence on economic development is confirmed by the results of numerous studies. 
The number and the geographical coverage of the related research have been increasing recently, thus confirming the topicality of the problem of institutions and institutional changes in today's conditions (Draskovic et al., 2017). However, many research problems remain understudied concerning institutions of the social sector: social security, healthcare, education. The reasons for such delay in the research process are related to both conceptualization of these institutions themselves and, consequently, to the complexity of empirical studies on the related institutional changes as well as to the specific place and role of social sector in national economy.

Criticism of various approaches applied to measure the quality of institutions was not the aim of our research. These approaches were developed in certain contexts, where they were successfully applied. However, explaining the need for a completely new approach to assessing the quality of social institutions was not our goal either. The aim of our study is to assess institutional quality of the social sector basing on social indicators of the countries with different socioeconomic models.

\section{Literature review}

Complex structure of the social sector, correlations between social, economic and ecological indicators contribute to the use of the integrated approach aiming to evaluate the quality of this sector. Thus, institutional quality issues are often investigated in the context of economic growth and economic performance. Studies on the role of institutions in economic development are widely represented by the World Bank. The methodology of the Worldwide Governance Indicators (WGI) (Kaufmann et al., 2005, 2009, 2010; Acemoglu, Robinson, 2008) covers over 200 countries and territories, measuring six dimensions of governance: Voice and Accountability, Political Stability and Absence of Violence/Terrorism, Government Effectiveness, Regulatory Quality, Rule of Law, and Control of Corruption. This methodology has been in use since 1996.

J. Aron (2000) explores the role of public and private institutions in economic growth since paucity and weakness of both macroeconomic and institutional data for many developing countries preclude robust policy interpretations on a country-by-country basis (Besciu, Androniceanu). Moreover, the issue with the influence of institutional quality on economic growth of resource-oriented and transition economies has become particularly relevant as institutions tend to have a crucial impact in the post-socialist context especially (Pilc, 2018; Androniceanu, 2017). Vitola A., Senfelde M. (2015, p. 278) examined the role of institutions in economy stating that "institutions affect investment in physical and human capital as well as the organisation of production. Quantitative research proves that institutional quality accounts for the greatest part of the differences in worker output and income around the world".

The institutional quality of the social sector of the economy determines macroeconomic dynamics level (Lyulyov et al., 2018; Došenović Bonča, P. et al., 2018; Kyrychenko et al., 2018; Kartashov, 2007; Melnyk et al., 2018), economic performance (Efendic, Pugh, 2015) and business-cycle dynamics (Lunyakov et al., 2013; Lubis, 2018; Sanusi et al., 2017). Bhandari M. (2017) states that proper institutional architecture is important for sustainable development. Institutional architecture has global importance not only for governance, but also for national and regional governances. Proper governance is needed in developing, monitoring and implementing policies that are needed to meet the three pillars - social, environmental and economic ones - of sustainable development (Bartkowiak-Bakun, 2017). Moskovicz A. (2018) stresses that institutional quality basically means the adaptation of resources to the changing environment, taking advantage of opportunities and evaluating risks according to objectives and goals. Buriak A. and Sysoyeva L. (2014) consider institutional issues among the set of 
financial systems' characteristics which make them more exposing to systemic risks. Bruinshoofd A. (2016) considers institutional quality as a broader concept that encompasses legislation, individual rights and government regulation and services of high quality. Nifo A., Vecchione G. (2014) studied the impact of institutional quality on the migration of skilled labour. The link between institutional quality of the social sector and the level of lifelong education system is investigated by Petrushenko Yu. (2017), Poliakh S. and Nuriddin A. (2017), Kolářová E. and Kolářová V. (2017), Máté D. and Darabos E. (2017), Harshad D. (2017) considers that institutional quality of the social sector is based on inventions and discoveries, intellectual work, keeping record of memory, knowledge transfer etc.

\section{Methodological approach}

Reliability and internal consistency of the indicators were verified using the Cronbach's alpha, calculated by comparing the scores for each scale object with the total score for each observation, and then comparing them with the variance for all individual elements:

$$
\alpha=\left(\frac{k}{k-1}\right) \times\left(1-\frac{\sum_{i=1}^{k} \sigma_{y i}^{2}}{\sigma_{x}^{2}}\right)
$$

where $\sigma_{y i}^{2}$ - the variance of indicator $i ; \sigma_{x}^{2}$ - the variance of all indicators; $k$ - the number of indicators in the set.

Cronbach's alpha ranges from 0 to 1, providing an overall assessment of the indicator's reliability. If all indicators are completely independent (i.e., do not correlate or do not have a general covariance), then $\alpha$ equals to 0 ; if all elements have high covariances, then $\alpha$ will approach 1, when the number of elements on the scale verges to infinity. In other words, according to (Goforth, 2015), the higher is the coefficient $\alpha$, the more elements have a common covariance and, perhaps, measure the same basic concept.

Verification of reliability in the selected indicators (using the Cronbach's alpha) and subsequent calculations were carried out using STATA/MP 13.0. The obtained value $\alpha$ for our indicator set is 0.8421 , which is greater than the critical value of 0.7 and points at a "good" level of internal consistency (according to Bland, Altman, 1997).

The next important step in calculating the QISS index is to determine the weight of each indicator. To solve this problem, either statistical analysis, or mathematical modelling can be used. The latter, in our opinion, will allow us consider the complexity and multidimensionality of the social sector more fully, determine the list of factors, the strength and their influence on the effectiveness of its functioning, preventing the subjectivity inherent in expert evaluations. One of the methods of mathematical modelling and statistical analysis is the principal component analysis. With this method, it is possible to define the list of key components (factors) that explain the indicators' variance, prevent duplication of information and facilitate the results' interpretation.

The first stage in the algorithm of the main component analysis is the unification of these indicators. Different measurement units and the scale of original source data may distort the results. So, the main component will be set by the exponent that has the highest variance value. To unify the indicators intensity and coordinate their influence, the normalization approach is also required.

To convert the indicators, the following equations are used (Nikolaev et al., 2009):

a) when the highest quality indicator corresponds to its minimum value: 


$$
\tilde{X}=\frac{X-X_{\min }}{X_{\max }-X_{\min }}
$$

b) when the highest quality indicator corresponds to its maximum value:

$$
\tilde{X}=\frac{X_{\max }-X}{X_{\max }-X_{\min }},
$$

c) when the highest quality indicator corresponds to its defined value:

$$
\tilde{X}=1-\frac{\left|X-X_{o p t}\right|}{\left[\left(X_{o p t}-X_{\min }\right) \times\left(X_{\max }-X_{o p t}\right)\right]},
$$

where $\tilde{X}$ - unified data, $X$ - primary data, $X_{\min }$ - the minimum value of primary data, $X_{\max }-$ the maximum value of primary data, $X_{o p t}$ - the optimal value of primary data.

Due to these changes we get unified data, the possible values of which will be in the range from 0 to 1 . At the same time, the best value of the indicator from the position of social institutions quality corresponds to one, while the worst one - to zero.

The nature of the principal component analysis (PCA) consists in the decrease in the number of output indicators that have greater variability. From the mathematical point of view, the basic set of variables is replaced by a new set of uncorrelated variables (components), which are primary weighted variables. In this case, the sum of the squares of weight coefficients will always be 1 .

New variables are the main components $(p c)$. They will gradually choose the variability of base indicators and, accordingly, the first principal component $(p c 1)$ will have the largest value of the sample variance. In the future, the algorithm of PCA will select the second principal component upon the fulfillment of conditions regarding the equality to the unity of the sum of squares of weight coefficients, the lack of correlation with $p c l$ and the maximum value of residual variance, and so on, until the main components will not select all the variance.

\section{Conducting research and results}

\subsection{Institutional quality of the social sector: the search for measuring instruments}

The issues which should be addressed while studying this problem are the following:

- What measurements are the most appropriate to the task in hand and methodologically correct: integral indicators or a set of individual indicators?

- How will the parameter (parameters) allow us make a comparison between individual countries or regions to reflect the dynamics of institutional changes?

- What is the relationship between the quality of social institutions and economic development in countries with different models?

Integral indicators or a set of individual partial indicators

The definition of institutional quality is challenging because of a complex nature of institutions. In general, we should mention another compulsory characteristic of institutional quality which is the ability of institutions to change. North D. (1997, p. 73) considered the mechanisms that ensure their implementation and behavioral norms which structure repeated interrelations between people. We will consider the institutional quality of social sector, firstly, as its ability to provide services in accordance with social guarantees (standards), and secondly, as the ability to change in accordance with the needs of socioeconomic development. 
We tried to examine the disadvantages of the existing parameters. The following principles for calculating the institutional quality index of social sector were defined:

1. Social measures of outcomes. We propose to calculate the index based on the indicators characterizing the functions of individual institutions in the social sector. This index should not include the indicators of costs and social expenditures.

2. Objectivity means that a generalized estimator should not be based on expert values of institutions, but indicators should be provided by official statistics. Their use makes it possible to undertake an assessment as maximally objective and comparable for individual countries.

3. Complexity and multidimensionality: this index should summarize all possible aspects of activity in the social sector. 20 indicators for three groups (education, health and social protection), which are represented by official statistics, are included in calculations. The complex one-dimensional parameter allows us consider a wide range of components and classify countries according to the estimates. It has more operationality and makes it possible to reduce errors in measuring institutional quality.

The questions of applying a complex (aggregated) indicator or a set of partial ones for the institutional quality analysis do not have an unanimous answer. Most of the available measures are complex, but they are poorly informative for study the institutional quality of the social sector. Let us dwell on individual indicators which are typically used to analyze economic development and the quality of life.

Human Development Index (HDI), used by the United Nations Development Program, includes both social and economic components. To achieve the tasks outlined above, we consider institutional quality assessment for the social sector as an intermediate stage of research. Sameas HDI, other indices (the Better Life Index, for example) also have the economic component in the basis of their calculations.

We turn our attention to such indicator as the Knowledge Economy Index (KEI), which is calculated by the World Bank. It is one of the most complex indicators, which is considering institutional regime, incentives for effective knowledge creation, dissemination and use of the already existing knowledge. However, this indicator cannot be treated as the institutional quality index of the social sector, since its purpose is to assess the transition to knowledge economy.

Also, we should take into account the Social Progress Index (SPI). This indicator has been designed by Stern S., Wares A., Hellman T. (2016) to measure the social progress in countries and compare them on various aspects of social progress. The unconditional advantage of this index is that it is based on the approach to results, the so-called output but not input characteristics. However, we do not consider some indicators of this index necessary for assessing the institutional quality of social sector, in particular, environmental quality.

\subsection{Data description}

Therefore, to build the index, we selected the indicators corresponding to the above goals. They allow us assess the institutional quality of social sector in the most stable and transparent way, forming the primary array of information support for state regulation of institutional changes. These tasks have identified the key criteria for selecting the primary indicators.

First of all, indicators should be formed from open public sources. This requirement is the basic one, although for the analysis of complex research objects, which include institutions and institutional changes, it is often necessary to use the factors that are difficult to measure. 
This will ensure the transparency of calculations, the possibility of their reproduction, considering the growth of time series and the prospects for further index improvement.

Also, indicators should be strong enough. To achieve the set goals, the selection process for proposed indicators should be accompanied by the assessment of their significance. Mathematical complexity of analysis and calculations will grow with the increasing number of indicators and it can be compensated using various software packages. The complexity of findings and the risks of making erroneous management decisions will certainly increase (Lazányi et al., 2017).

The Institutional Quality Index of social sector: the calculation methodology

To calculate the Institutional Quality Index of Social Sector (IQSS), we offer a list of indicators that measure the effectiveness of institutions and their changes in the social sector (Table 1).

Table 1. The list of indicators included in the calculation of the Institutional Quality Index of the social sector

\begin{tabular}{|c|c|c|c|}
\hline $\begin{array}{l}\text { Group } \\
\text { of indicators }\end{array}$ & $\begin{array}{l}\text { Indicator } \\
\text { (units) }\end{array}$ & Designation & Description of the indicator \\
\hline \multirow{7}{*}{ Healthcare } & $\begin{array}{l}\text { Birth rate (per } \\
1,000 \text { people) }\end{array}$ & birth rate & $\begin{array}{l}\text { The number of births during the year (per } 1000 \\
\text { people). }\end{array}$ \\
\hline & $\begin{array}{l}\text { Mortality rate } \\
\text { (per 1,000 people) }\end{array}$ & death rate & $\begin{array}{l}\text { The number of deaths during the year (per } 1000 \\
\text { people). }\end{array}$ \\
\hline & $\begin{array}{l}\text { Tuberculosis } \\
\text { incidences } \\
\text { (per } 100,000 \text { people) }\end{array}$ & October & $\begin{array}{l}\text { Tuberculosis incidences (new and recurrence), } \\
\text { (per 100,000 people). All types of tuberculosis, } \\
\text { including HIV-infected persons, are considered. }\end{array}$ \\
\hline & $\begin{array}{l}\text { Life expectancy } \\
\text { (in years) }\end{array}$ & expectancy & $\begin{array}{l}\text { The number of years a newborn can live if the } \\
\text { death rate at the time of his birth remained the } \\
\text { same throughout his life. }\end{array}$ \\
\hline & $\begin{array}{l}\text { Adult mortality } \\
\text { (per } 1,000 \text { people) }\end{array}$ & mortal adult & $\begin{array}{l}\text { The death probability of an adult aged } 15 \text { to } 60 \\
\text { years. }\end{array}$ \\
\hline & $\begin{array}{l}\text { Infant mortality } \\
\text { (for } 1000 \text { newborns) }\end{array}$ & mortality & $\begin{array}{l}\text { The number of infant deaths during one year (per } \\
1,000 \text { newborns). }\end{array}$ \\
\hline & $\begin{array}{l}\text { Successful treatment } \\
\text { of tuberculosis } \\
\text { (\% of new incidences) }\end{array}$ & tubertrtment & $\begin{array}{l}\text { The percentage of tuberculosis incidences (new } \\
\text { and recurrence) and successfully completed } \\
\text { treatment in a corresponding year. }\end{array}$ \\
\hline \multirow{4}{*}{$\begin{array}{l}\text { Social } \\
\text { protection }\end{array}$} & $\begin{array}{l}\text { Unemployment } \\
\text { (\% of the number } \\
\text { of employees) }\end{array}$ & unemploy & $\begin{array}{l}\text { The percent of people in working age who are out } \\
\text { of work. }\end{array}$ \\
\hline & $\begin{array}{l}\text { Adolescent fertility } \\
\text { (The number of } \\
\text { births per } 1,000 \\
\text { women aged } 15-19 \text { ) }\end{array}$ & adolfert & $\begin{array}{l}\text { The number of births among women aged 15-19 } \\
\text { years (per } 1000 \text { women). }\end{array}$ \\
\hline & $\begin{array}{l}\text { Age dependence } \\
\text { (\% of the number } \\
\text { of working-age } \\
\text { population) }\end{array}$ & agedpndnc & $\begin{array}{l}\text { The number of people under the age of } 15 \text { years } \\
\text { and after } 64 \text { years in relation to the number of } \\
\text { people aged } 15 \text { to } 64 \text { years. The values are given } \\
\text { in the proportion of age-dependent people of } \\
\text { working age (per } 100 \text { people). }\end{array}$ \\
\hline & $\begin{array}{l}\text { Unprotected } \\
\text { (vulnerable) } \\
\text { employment } \\
\text { (\% of the number } \\
\text { of employees) }\end{array}$ & vulnerempl & $\begin{array}{l}\text { The number of employees in the areas sensitive to } \\
\text { changes in the business cycle (self-employed } \\
\text { persons or employed in the household). }\end{array}$ \\
\hline
\end{tabular}




\begin{tabular}{|c|c|c|c|}
\hline \multirow{9}{*}{ Education } & $\begin{array}{l}\text { Primary education } \\
\text { coverage ( } \% \text { of the } \\
\text { total population) }\end{array}$ & schenrlprimary & $\begin{array}{l}\text { The share of population, regardless of age, that is } \\
\text { covered by primary education. }\end{array}$ \\
\hline & $\begin{array}{l}\text { Employed with a } \\
\text { level of education } \\
\text { below the basic } \\
(\% \text { of the total) }\end{array}$ & emplLessbasic & $\begin{array}{l}\text { The share of employees with a level of education } \\
\text { below the basic (according to the ISCED-11 } \\
\text { classification). }\end{array}$ \\
\hline & $\begin{array}{l}\text { Employed with a } \\
\text { formal education } \\
\text { (\% of the total) }\end{array}$ & emplschool & $\begin{array}{l}\text { The share of employees with formal education } \\
\text { (according to the ISCED-11 classification). }\end{array}$ \\
\hline & $\begin{array}{l}\text { Employed with a } \\
\text { Bachelor's degree } \\
(\% \text { of the total })\end{array}$ & emplbach & $\begin{array}{l}\text { The share of employees with a Bachelor's degree } \\
\text { or equivalent education level (according to the } \\
\text { ISCED-11 classification). }\end{array}$ \\
\hline & $\begin{array}{l}\text { Employed with a } \\
\text { Master's degree } \\
\text { (\% of the total) }\end{array}$ & emplmasters & $\begin{array}{l}\text { The share of employees with a Master's degree } \\
\text { or equivalent educational level (according to the } \\
\text { ISCED-11 classification). }\end{array}$ \\
\hline & $\begin{array}{l}\text { Employed without } \\
\text { a defined level of } \\
\text { education ( } \% \text { of the } \\
\text { total) }\end{array}$ & $\begin{array}{l}\text { Level not } \\
\text { stated }\end{array}$ & $\begin{array}{l}\text { The share of employees without a defined level of } \\
\text { education (according to the ISCED-11 } \\
\text { classification). }\end{array}$ \\
\hline & $\begin{array}{l}\text { Duration of } \\
\text { compulsory } \\
\text { schooling (years) }\end{array}$ & Durcomedu & $\begin{array}{l}\text { A number of years of compulsory school } \\
\text { attendance. }\end{array}$ \\
\hline & $\begin{array}{l}\text { Persons studying } \\
\text { abroad }(\%)\end{array}$ & Outbound & The share of students studying abroad. \\
\hline & $\begin{array}{l}\text { Persons studying in } \\
\text { other countries }(\%)\end{array}$ & Inbound & The share of foreign students. \\
\hline
\end{tabular}

Some of the related indicators are not included in the proposed list due to their inadequate representation by countries. These are the indicators of adequacy and efficiency of social protection programs, labour market, and healthcare. Ddatabases on the education outcomes of pupils and students (PISA, EGRA etc.) have been also duly noted. We hope that these indicators could be added to the proposed list in the future once they become more complete in terms of data availability.

To calculate the QISS index, we formed a database covering 25 countries, the selection of which was determined by the need to consider the impact of the difference in economic development, the history of institutional changes, the socio-political model of public administration, the specifics of social protection programs and the development of social sphere overall. The division of countries into groups was based on the UN classification (2014).

The first group of countries is presented by economically developed countries that together form the G7 group. They are characterized by high indicators of socioeconomic development, the system of institutions, and a series of their transformations. This group includes Canada, France, Germany, Italy, the United Kingdom, USA.

The second group includes economically developed countries, members of the European Union and Turkey. These countries are interesting from the standpoint of transforming institutions caused by integrational processes, since unification of systems and programs can supposedly ensure the development of social sector. This second group includes Austria, Belgium, Denmark, Finland, the Netherlands, Portugal, Sweden and Turkey.

The countries of the Baltic, Eastern and South-Eastern Europe, new members of the European Union belong to the third group. Institutional changes associated with the processes of economic restructuring and governance at the stage of joining the EU occurred at a relatively 
rapid pace. Therefore, experience of such countries is especially important for Ukraine at the present stage. The third group of countries comprises Croatia, Czech Republic, Estonia, Latvia, Lithuania, Poland, Romania.

The last group includes Armenia, Belarus, Georgia, Kazakhstan, the Russian Federation, Ukraine. Tamilina L., Baklanova E. (2012) noted that institutions in these post-Soviet republics began to change, and the same time had a single goal (the introduction of market institutions). It was implemented in relatively short terms.

As a result, we have received a data set, including 20 indicators divided into three groups for 25 countries for the period of 2008-2014.

\subsection{Results}

Table 2 presents the calculation results for the principal components parameters: an eigenvalue, the extent to which the variance of the next component is less than the previous one (difference), the proportion of the total variance and the cumulative value of total variance.

Table 2. Calculating the parameters of principal components

\begin{tabular}{r|rrrr}
\hline Component & Eigenvalue & Difference & Proportion & Cumulative \\
\hline Comp1 & 6.11249 & 2.17376 & 0.3056 & 0.3056 \\
Comp2 & 3.93874 & 1.65142 & 0.1969 & 0.5026 \\
Comp3 & 2.28731 & .692291 & 0.1144 & 0.6169 \\
Comp4 & 1.59502 & .478921 & 0.0798 & 0.6967 \\
Comp5 & 1.1161 & .113473 & 0.0558 & 0.7525 \\
Comp6 & 1.00263 & .151276 & 0.0501 & 0.8026 \\
Comp7 & .851354 & .0564663 & 0.0426 & 0.8452 \\
Comp8 & .794887 & .184071 & 0.0397 & 0.8849 \\
Comp9 & .610817 & .111246 & 0.0305 & 0.9155 \\
Comp10 & .499571 & .0639211 & 0.0250 & 0.9404 \\
Comp11 & .43565 & .112817 & 0.0218 & 0.9622 \\
Comp12 & .322833 & .119658 & 0.0161 & 0.9784 \\
Comp13 & .203175 & .0868664 & 0.0102 & 0.9885 \\
Comp14 & .116309 & .0737594 & 0.0058 & 0.9943 \\
Comp15 & .0425491 & .00492792 & 0.0021 & 0.9965 \\
Comp16 & .0376212 & .0217251 & 0.0019 & 0.9984 \\
Comp17 & .0158961 & .00299505 & 0.0008 & 0.9991 \\
Comp18 & .012901 & .00886825 & 0.0006 & 0.9998 \\
Comp19 & .00403277 & .00392508 & 0.0002 & 1.0000 \\
Comp20 & .000107687 & & 0.0000 & 1.0000 \\
\hline
\end{tabular}

Thus, higher variance occurs in the first principal component, overall, it characterizes $30.56 \%$ of the total variance in initial indicators, the second component has the variance value of 3.93 and characterizes $19.69 \%$ of the total variance. Cumulatively, the first and the second components provide explanations for $50.26 \%$ of the variance and so on. This information is necessary to choose the number of principal components that will be used for further analysis, interpretation of indicators and index determination.

Using the Kaiser criterion, only components whose eigenvalue is at least 1 are selected. In our case, these are the first six components, which cumulatively explain $80.26 \%$ of the original variance. You can confirm the selection graphically using the screen test (Graph 1), where the number of points to the line determines the number of principal components. 
The interpretation of principal components is carried out based on the matrix of factor loadings, which are the correlation values between the primary indicators and the corresponding component. To increase the informativeness, various kinds of rotation can be used.

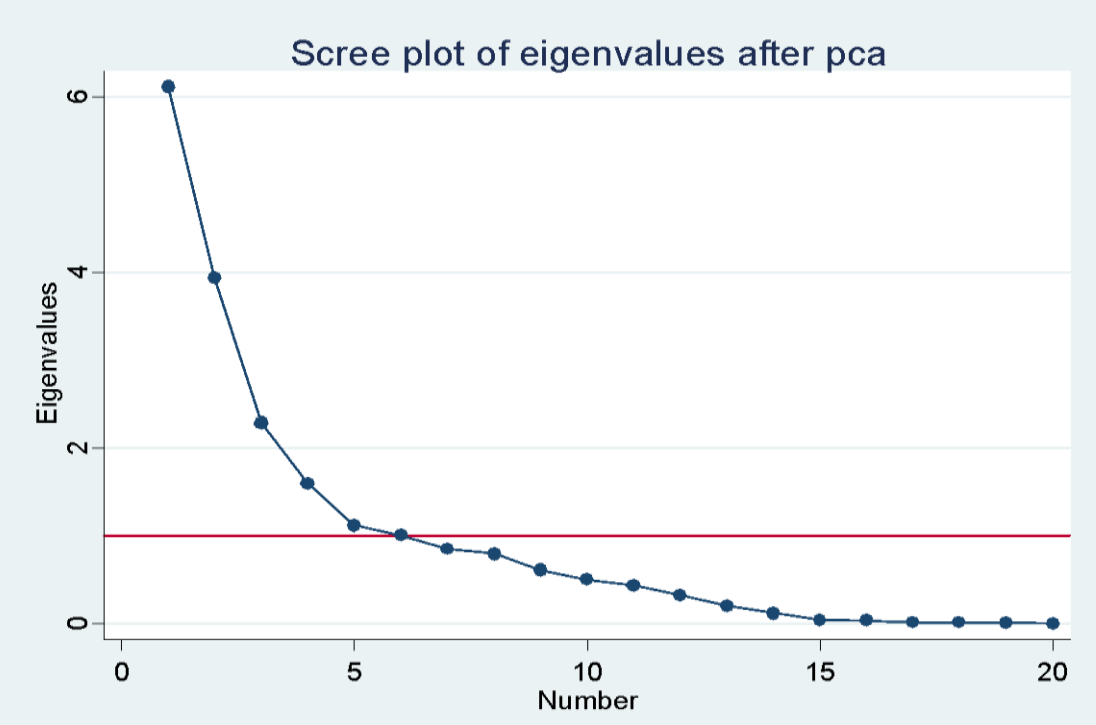

Graph 1. The selection of principal components by the screen test

After the rotation by the VARIMAX method, we obtained the following values of eigenvectors in 6 selected principal components with the correlation value less than 0.3 which is considered insignificant and excluded from Table 3.

Table 3. The factor loadings of principal components using the VARIMAX rotation

\begin{tabular}{|c|c|c|c|c|c|c|}
\hline Variable & Comp1 & Comp2 & Comp3 & Comp4 & Comp5 & Comp 6 \\
\hline birthrate & & & & & & \\
\hline deathrate & & & 0.3467 & & & \\
\hline Inctuber & 0.3239 & & & & & \\
\hline liexpectancy & 0.3510 & & & & & \\
\hline mortaladult & 0.3093 & & & & & \\
\hline mortalinf & 0.3861 & & & & & \\
\hline tubertrtmnt & & & & & & 0.4150 \\
\hline unempltot & & & & & & 0.6892 \\
\hline adolfert & 0.3951 & & & & & \\
\hline agedpndnc & -0.3306 & & & & & \\
\hline vulnerempl & & & & & & \\
\hline schenrlpri y & & & & & 0.6456 & \\
\hline empl Lessba c & & 0.5712 & & & & \\
\hline emplschool & & 0.5815 & & & & \\
\hline emplbach & & & & -0.5308 & & \\
\hline emplmasters & & 0.3412 & & 0.5793 & & \\
\hline Levelnotst $\sim$ d & & & & 0.4411 & 0.3447 & \\
\hline Durcomedu & & & 0.4307 & & & \\
\hline outbound & & & 0.6449 & & & \\
\hline Inbound & & & & & & 0.3250 \\
\hline
\end{tabular}


It is difficult to establish the essential features of principal components clearly, but we can make a few conclusions in the first approximation, which will be refined in further research.

The quality of social institutions will be primarily determined by their ability to ensure the continuation of average life expectancy and to maintain an adequate level of health (principal component 1). The second and third components are characterized by the relationship between the results of education and further employment. The quality of social protection institutions affects the index variance to the least extent.

The coefficients of indicator correlation are approximately at the same level and characterize a single level of factor loading of components.

Thus, the principal component analysis shows the calculation of index with equal weight coefficients for established factor loadings of output indicators on principal components (Table 4).

Table 4. Factor loadings of output indicators for main components

\begin{tabular}{lccccccccc}
\hline \multicolumn{1}{c}{ Country } & $\begin{array}{c}\text { Country } \\
\text { group }\end{array}$ & 2007 & 2008 & 2009 & 2010 & 2011 & 2012 & 2013 & 2014 \\
\hline Canada & 1 & 6,683 & 6,380 & 6,441 & 6,539 & 6,535 & 6,696 & 6,689 & 6,701 \\
\hline France & 1 & 6,424 & 6,072 & 6,377 & 6,394 & 6,387 & 6,334 & 6,068 & 5,989 \\
\hline Germany & 1 & 6,366 & 5,982 & 6,277 & 6,329 & 6,286 & 6,405 & 6,263 & 5,942 \\
\hline Italy & 1 & 5,471 & 5,121 & 5,454 & 5,469 & 5,404 & 5,276 & 5,148 & 5,121 \\
\hline UK & 1 & 6,320 & 5,982 & 6,269 & 6,380 & 6,370 & 6,540 & 6,498 & 6,414 \\
\hline USA & 1 & 6,741 & 6,487 & 6,484 & 6,489 & 6,532 & 6,540 & 6,523 & 6,563 \\
\hline Austria & 2 & 6,276 & 6,011 & 6,300 & 6,361 & 6,329 & 6,224 & 6,187 & 6,350 \\
\hline Belgium & 2 & 5,914 & 5,598 & 6,063 & 6,091 & 6,099 & 6,064 & 5,979 & 6,091 \\
\hline Denmark & 2 & 5,513 & 5,177 & 5,428 & 5,549 & 5,543 & 5,632 & 5,651 & 5,623 \\
\hline Finland & 2 & 5,900 & 5,640 & 5,910 & 5,986 & 6,048 & 6,165 & 6,163 & 6,094 \\
\hline Netherlands & 2 & 6,068 & 5,789 & 6,054 & 6,093 & 6,042 & 6,065 & 5,805 & 5,741 \\
\hline Portugal & 2 & 4,360 & 4,066 & 4,322 & 4,332 & 4,411 & 4,302 & 4,191 & 4,447 \\
\hline Sweden & 2 & 6,018 & 5,777 & 6,170 & 6,281 & 6,321 & 6,245 & 6,478 & 6,493 \\
\hline Turkey & 2 & 2,528 & 2,512 & 2,378 & 2,483 & 2,471 & 2,484 & 2,520 & 2,468 \\
\hline Croatia & 3 & 4,776 & 4,663 & 4,670 & 4,707 & 4,554 & 4,255 & 4,261 & 4,550 \\
\hline Czech Republic & 3 & 5,580 & 5,464 & 5,586 & 5,648 & 5,665 & 5,702 & 5,649 & 5,752 \\
\hline Estonia & 3 & 5,195 & 5,261 & 5,155 & 5,129 & 5,264 & 5,422 & 5,512 & 5,480 \\
\hline Latvia & 3 & 4,458 & 4,681 & 4,465 & 4,478 & 4,571 & 4,620 & 4,656 & 4,572 \\
\hline Lithuania & 3 & 4,880 & 5,049 & 4,804 & 4,743 & 4,748 & 4,770 & 4,831 & 5,087 \\
\hline Poland & 3 & 4,938 & 4,963 & 5,061 & 5,119 & 5,110 & 5,124 & 5,040 & 5,141 \\
\hline Romania & 3 & 3,780 & 3,817 & 3,763 & 3,780 & 3,832 & 3,767 & 3,781 & 3,675 \\
\hline Armenia & 4 & 4,710 & 4,583 & 4,420 & 4,351 & 4,368 & 4,281 & 4,202 & 3,763 \\
\hline Georgia & 4 & 3,730 & 3,610 & 3,594 & 3,562 & 3,567 & 3,536 & 3,580 & 3,791 \\
\hline Russian & 4 & 4,721 & 4,998 & 4,718 & 4,804 & 4,880 & 4,944 & 4,855 & 4,841 \\
\hline Federation & 4 & 4,609 & 4,783 & 4,480 & 4,696 & 4,732 & 4,751 & 4,627 & 4,510 \\
\hline Ukraine & & & & & & & & &
\end{tabular}

\subsection{The analysis of findings}

Now we can form the rating of countries according to the Institutional Quality Index in the social sector in 2014 (Table 5). 
Table 5. Countries' rating according to the Institutional Quality Index in the social sector

\begin{tabular}{lccclccc}
\hline \multicolumn{1}{c}{ Country } & Group & Index & $\begin{array}{c}\text { Place in } \\
\text { rating }\end{array}$ & Country & Group & Index & $\begin{array}{c}\text { Place in } \\
\text { rating }\end{array}$ \\
\hline Canada & 1 & 6,701094 & 1 & Poland & 3 & 5,140621 & 14 \\
\hline USA & 1 & 6,562521 & 2 & Italy & 1 & 5,121007 & 15 \\
\hline Sweden & 2 & 6,493431 & 3 & Lithuania & 3 & 5,087297 & 16 \\
\hline UK & 1 & 6,413585 & 4 & $\begin{array}{l}\text { Russian } \\
\text { Federation }\end{array}$ & 4 & 4,840563 & 17 \\
\hline Austria & 2 & 6,349879 & 5 & Latvia & 3 & 4,571516 & 18 \\
\hline Finland & 2 & 6,094234 & 6 & Croatia & 3 & 4,55048 & 19 \\
\hline Belgium & 2 & 6,090903 & 7 & Ukraine & 4 & 4,510054 & 20 \\
\hline France & 1 & 5,988771 & 8 & Portugal & 2 & 4,447134 & 21 \\
\hline Germany & 1 & 5,941608 & 9 & Georgia & 4 & 3,791005 & 22 \\
\hline Czech Republic & 3 & 5,752066 & 10 & Armenia & 4 & 3,762599 & 23 \\
\hline Netherlands & 2 & 5,741049 & 11 & Romania & 3 & 3,675285 & 24 \\
\hline Denmark & 2 & 5,622551 & 12 & Turkey & 2 & 2,468144 & 25 \\
\hline Estonia & 3 & 5,479711 & 13 & & & & \\
\hline & & & & & & &
\end{tabular}

\section{Conclusion}

In this article we continue our research on the functioning of the social sector under conditions of economy's transition in Ukraine. We have attempted to assess institutional changes and compare them with good practices based on the existing indicators, and then substantiate the institutional structure of social sector that is adequate to the needs of transition economy.

The result of this study became the measuring instrument of institutional quality in social sector. The search for it is an attempt to explore the problem more extensively, as stated by Bruinshoofd A. (2016). He investigated the link between institutional quality and economic development. Taking the conclusion made by this researcher ("institutional quality allows countries to achieve long-term convergence of incomes") as a starting point, we have tried here to assess the quality of social institutions, because we consider that the social sphere development determines the development of human capital, which today is the main determinant of strategic competitive advantages of the country.

The interpretation of findings in the context of conclusions made by (Bruinshoofd, 2016) is not ambiguous. There is no linear relationship between the level of the country's economic development and institutional quality of social sector (Table 5), which can be explained by different models of social protection (sociodemocratic, liberal, conservative), but requires more in-depth research. It is interesting that the differences in GDP per capita between the countries in question is quite significant (Graph 2), while differences in the index values are mostly insignificant. 


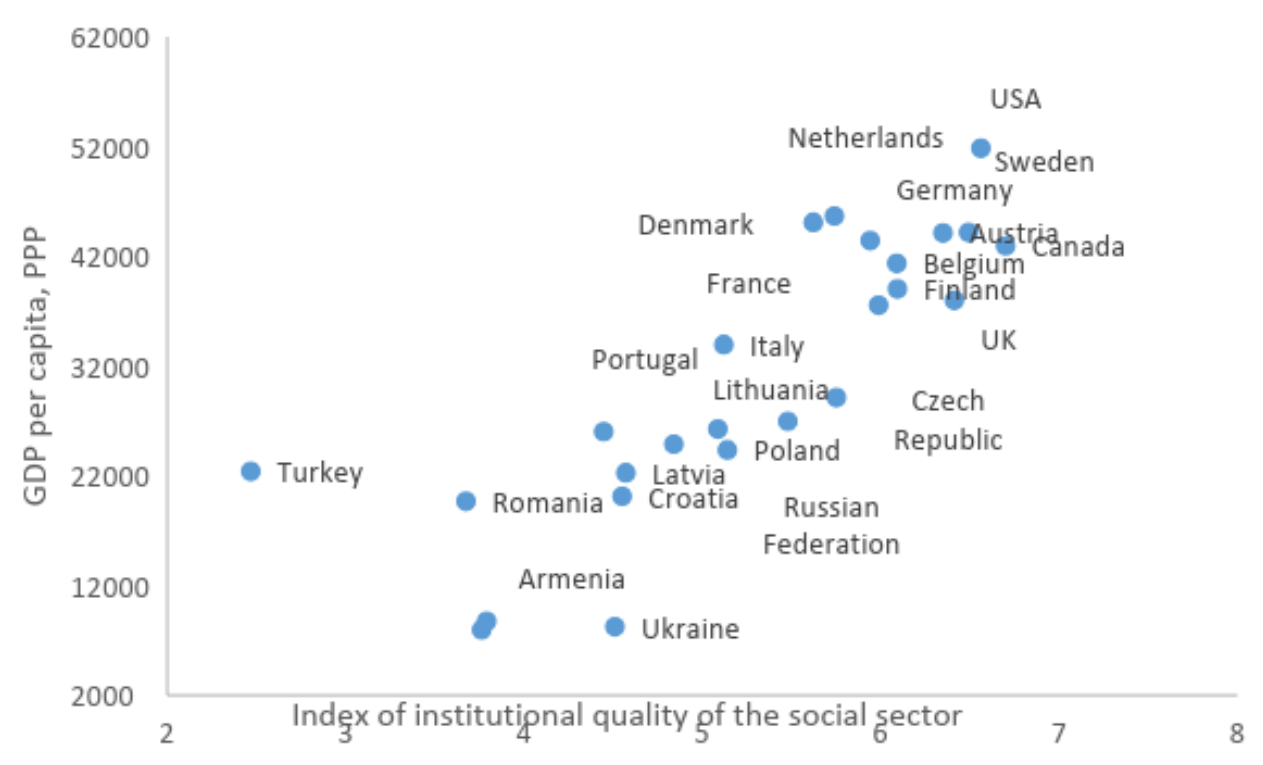

Graph 2. The ratio of Institutional Quality Index in the social sector and GDP per capita, calculated based on purchasing power parity as of 2014

Explanation for this can be probably found in the fact that governments of all these countries are guided by current social standards and guarantees that are sufficiently 'stable'. Their change can be seen as the formation of a new institution of social guarantees, accompanied by serious institutional changes in the economy.

Another interpretation of the obtained indicators, which are included in the calculation of the index for countries with a high level of socioeconomic development, is that they are close to the upper boundary. As we already noted, it would be more informative to expand the list of indicators that characterize institutional quality, however, official statistics, especially for the groups of countries under consideration provides rather limited data.

We believe that these findings should be complemented by an examination of relationship between institutional quality and inequality in income distribution. This aspect of our research will be a continuation of the relevant research study (Chong, Calderón, 2000) and will provide deeper explanation of the results.

We are aware that the conducted study does not provide an exhaustive assessment of the social sector quality, but we believe that further improvement of institutional quality measuring instruments can be useful for solving some important issues, including the assessment of macroimpact of the social sector. This problem is very relevant for today's economic development. Approaches to assessing the social impact of the third sector in the macroeconomic dimension are in demand. The approaches proposed by Anheier H. K., Krlev G., Preuss S., Mildenberger G., Einarsson T. (2014) and B. Enjolras (2016) focus exclusively on the impact assessment of the third sector, although institutional changes' evaluation in the social sector is interesting and useful.

Due to active development of impact investments, investors need unified information on the influence. In this context, development of measuring instruments of institutional quality components in the social sector can be interesting, especially when the existing approaches to assessing the impact are very limited.

The results of the study can be used as a starting point for assessing the relationship between the level of a country's development, its social model and the quality of its institutional 
changes. Thus, policymakers are able to receive information to evaluate the effectiveness of the decisions taken.

Our findings also demonstrate the relevance of the proposed index while assessing the institutional quality of the social sector. The task for the nearest future is to analyze the relationship between the institutional quality of the social sector and the dynamics of economic development indicators: the rates of GDP growth and GDP per capita.

\section{Acknowledgement} budget:

This article is part of the research work financed from the general fund of the state

1. "Modeling and forecasting the socio-economic-political road map of reforms in Ukraine for the transition to a sustainable growth model (state registration number: 0118U003569)".

2. "Improvement of the national system for counteracting the legalization of funds obtained in criminal way in the context of raising the financial and economic security of the state" (0117U002251).

\section{References}

Acemoglu, D., Robinson, J. (2008). The Role of Institutions in Growth and Development. The International Bank for Reconstruction and Development / The World Bank, Working Paper no.10 https://siteresources.worldbank.org/EXTPREMNET/Resources/4899601338997241035/Growth_Commission_Working_Paper_10_Role_Institutions_Growth_ Development.pdf

Androniceanu, A. (2017). Hospital management based on the relationship between doctors and patients. Administratie si Management Public, (29), 41-53.

Anheier, H. K., Krlev, G., Preuss, S., Mildenberger, G., Einarsson, T. (2014). Theory and empirical capturing of the third sector at the macro level. Deliverable 2.1 of the project: 'Impact of the Third sector as Social Innovation' (ITSSOIN), European Commission 7th Framework Programme, Brussels: European Commission, DG Research.

Aron, J. (2000). Growth and Institutions: A Review of the Evidence. The World Bank Research Observer, 15(1), 99-135.

Bartkowiak-Bakun, N. (2017). The diversity of socioeconomic development of rural areas in Poland in The Western Borderland and the problem of post-state farm localities. Oeconomia Copernicana, 8(3), 417-432. https://doi.org/10.24136/oc.v8i3.26.

Bland, J. M., Altman, D. G. (1997). Cronbach's Alpha. British Medical Journal, 314(7080).

Bruinshoofd, A. (2016). Institutional quality and economic performance. January 20, 2016. Available at: https://economics.rabobank.com/publications/2016/january/institutionalquality-and-economic-performance/.

Besciu, C. D., Androniceanu, A. (2017). The link between social inequalities, health' system characteristics and R\&D expenditure-worldwide evidence. Romanian Statistical Review, (2), 21-41.

Buriak, A., Sysoyeva, L. (2014). Development prerequisites for the regulatory approaches of the systemic risk regulation in finances. Economic Annals-XXI, 1-2(2), 20-23.

Chong, A., Calderón, C. (2000). Institutional Quality and Income Distribution. Economic Development and Cultural Change, 48(4), 761-786. 
Country classification. Data sources, country classifications and aggregation methodology (2014). Available at:

http://www.un.org/en/development/desa/policy/wesp/wesp_current/2014 wesp_country_classification.pdf.

Došenović Bonča, P., Tajnikar, M., Ponikvar, N., \& Mörec, B. (2018). Firm growth types and key macroeconomic aggregates through the economic cycle. Journal of Business Economics and Management, 19(1), 138-153. https://doi.org/10.3846/16111699.2017.1422798.

Draskovic, V., Popov, E., Peleckis, K. K. (2017). Modelling of Institutional Changes in Transition Countries - the Gap Between the Theory and Practice. Montenegrin Journal of Economics, 13(1), 125-140.

Efendic, A., Pugh, G. (2015). Institutional Effects on Economic Performance in Transition: a Dynamic Panel Analysis. Acta Oeconomica. Available at:

https://www.researchgate.net/profile/Adnan_Efendic2/publication/268977486_Institutio nal_effects_on_economic_performance_in_post-socialist_transition_a_dynamic_panel _analysis/links/547c2ec00cf205d16881d588/Institutional-effects-on-economicperformance-in-post-socialist-transition-a-dynamic-panel-analysis.pdf.

Enjolras, B. (2016). Assessing the macro socioeconomic impact of the third sector in Europe. Theoretical considerations and some empirical evidences TSI Working Paper Series No. 10. Seventh Framework Programme (grant agreement 613034), European Union. Brussels: Third Sector Impact. Retrieved from: http://thirdsectorimpact.eu/documentation/tsi-working-paper-no-10-assessing-macrosocio-economic-impact-third-sector-europe/.

Goforth, C. (2015). Using and Interpreting Cronbach's Alpha. Available at: http://data.library.virginia.edu/using-and-interpreting-cronbachs-alpha

Harshad, D. Dave (2017). An Inquiry on Social issues - Part 1. Business Ethics and Leadership, 1(2), 78-87.

Harshad, D. (2017). An Inquiry on Social Issues - Part 2. Business Ethics and Leadership, 1(3), 45-63.

Kartashov, G. (2007). Economic growth and quality of institutions of resource-oriented countries. Quantal, 2, 141-157. Access mode: http://quantile.ru/02/02-GK.pdf.

Kaufman, D., Kray, A., and Mastruzzi, M. (2007). Governance Matters VI: Governance Indicators for 1996-2006. World Bank.

Kaufman, D., Kray, A., and Mastruzzi, M. (2009). Governance Matters VIII: Aggregate and Individual Governance Indicators for 1996-2008. World Bank.

Kaufmann, D., Kraay, A., Mastruzzi, M. (2010). The Worldwide Governance Indicators: Methodology and Analytical Issues and, World Bank, September.

Kolářová, E., Kolářová, V. (2017). The Factors Influencing College Students' Choice of Elective Subjects. Journal of Competitiveness, 9(4), 40-49.

Kyrychenko, K., Lyeonov, S., Vasylieva, T., Lyulyov, O. (2018). Macroeconomic Stability and Its Impact on the Economic Growth of the Country. Montenegrin Journal of Economics, 14(1), 159-170.

Lazányi, K., Virglerová, Z., Dvorský, J., Dapkus, R. (2017). An analysis of factors related to "taking risks", according to selected sociodemographic factors. Acta Polytechnica Hungarica, 14(7), 35-50.

Lubis, A. S (2018). Corporate social responsibility in health sector: a case study in the government hospitals in Medan, Indonesia. Business: Theory and Practice, 19, 25-36. https://doi.org/10.3846/btp.2018.04 
Lunyakov, O. V., Vasilyeva, T. A., Leonov, S. V. (2013). Analysis of internal and external imbalances in the financial sector of Ukraine's economy. Actual Problems of Economics, 12(150), 176-184.

Lyulyov, O. V., Lyeonov, S. V., Vasylieva, T. A. (2018). Macroeconomic stability evaluation in countries of lower-middle-income economies. Bulletin of the National Mining University, 1, 138-146.

Máté, D., Darabos, E. (2017). Measuring the Accuracy of Self-assessment Among Undergraduate Students in Higher Education to Enhance Competitiveness. Journal of Competitiveness, 9(2), 78-92.

Melnyk, L., Sineviciene, L., Lyulyov, O., Pimonenko, T. and Dehtyarova, I. (2018). Fiscal decentralization and macroeconomic stability: the experience of Ukraine's economy. Problems and Perspectives in Management, 16(1), 105-114.

Moskovicz, A. (2018). Helping State Agent to understand the Private Sector. Financial Markets, Institutions and Risks, 2(1), 75-78.

Nifo, A., Vecchione, G. (2014). Do institutions play a role in skilled migration? The case of Italy. Available at: https://cream.conferenceservices.net/resources/952/3365/pdf/MGDNF2013_0088.pdf.

Nikolaev, I. A., Marchenko, T. E., Titova, M. V. (2009). Index of anti-crisis effectiveness. An analytical report, $34 \mathrm{p}$.

North, D. (1997). Institutions, Institutional Changes and Functioning of the Economy, $180 \mathrm{p}$.

Petrushenko, Yu. M., Vasylieva, T. A., Lyeonov, S. V., Vorontsova, A. S. (2017). Investment in the development of a system of long life education as an effective factor of socioeconomic development. Financial and credit activity: problems of theory and practice: collection of scientific works, 2(23), 426-436.

Pilc, M. (2017). Cultural, political and economic roots of the labor market institutional framework in the OECD and post-socialist countries. Equilibrium. Quarterly Journal of Economics and Economic Policy, 12(4), 713-731. https://doi.org/10.24136/eq.v12i4.37

Poliakh, S., Alikariyev, N. (2017). Evaluation Quality of Consumer Protection by Financial Markets Services. Financial Markets, Institutions and Risks, 1(3), 75-81.

Sanusi, K. A., Meyer, D., Ślusarczyk, B. (2017). The relationship between changes in inflation and financial development. Polish Journal of Management Studies, 16(2), 253-265.

Stern, S., Wares, A., Hellman, T. (2016). Social Progress Index 2016. Methodological Report. Available at: http://www.socialprogressimperative.org/wp-content/uploads/2016/07/SPI2016-Methodological-Report.pdf .

Tamilina, L., Baklanova, E. (2012). Methods of forming contract institutions as factors of economic growth: a comparative analysis. The Economy of Ukraine, 4, 4-15.

Vitola, A., Senfelde, M. (2015). The Role of Institutions in Economic Performance. Business: Theory and Practice, 16(3), 271-279. 